
ГУМАНІЗАЦІЯ ЗМІСТУ ПРОФЕСІЙНОЇ ПІДГОТОВКИ ФАХІВЦІВ ТЕХНІЧНОГО
ПРОФІЛЮ ЗАСОБАМИ ХУДОЖНЬОЇ ЛІТЕРАТУРИ

\title{
HUMANIZATION OF THE CONTENT OF PROFESSIONAL TRAINING FOR TECHNICIANS BY MEANS OF FICTION
}

У статті обґрунтовано доцільність використання інтегративного підходу до гуманізації професійної підготовки фрахівців технічного профрілю. Виявлено такі проблеми, як неінтегрованість знання, відірваність отриманих знань особистості від життєвих і професійних потреб, а також зростання пріоритету матеріального над духовним. Вирішення цих проблем лежить через розвиток гуманістичних парадигм, зокрема гуманізації змісту навчання у підготовці фрахівців технічного профрілю у закладах вищої та профресійно-технічної освіти. Обгрунтовано, що, виходячи з першочергових завдань новітньої педагогіки щодо виявлення гуманістичних аспектів у фаховому навчанні, доцільно послуговуватися засобами інтеграції знань, навичок цінностей учнів, аби сформувати творчу особистість профресіонала зі справжніми фраховими знаннями й уміннями, єдиними світоглядом і системою загальнолюдських і фрахових иінностей. Показано, що кожна навчальна дисципліна, інноваційні чи прожектерські проєкти виборюють власне місце у змісті освіти, який перетворюється в гігантське накопичення фрактів, де інорормація постійно поповнюється, але практично не згортається й не архівується. Висвітлено негативні наслідки некоректного використання загальнонаукової категорії «інтеграція», що веде до дискредитації ідеї інтегративного навчання, хоча існує низка наукових праць, де інтеграція професійного та загальнолюдського компонентів знань-цінностей у формуванні творчої особистості фрахівця досліджується як одне з найважливіших i найскладніших завдань сучасної освіти. Обгрунтовано, що значними резервами гуманізації змісту навчання володіють предмети природничого циклу, позаяк наукова думка переважно грунтується на інтегральних критеріях істини. Акцентовано, що одним із малопоширених, хоча ефективних засобів підвищення фраховоі підготовки є інтеграція технічних знань $і$ художньої літератури, наведено низку конкретних прикладів. Зроблено висновок, що технічні знання в гармонії з талановитим поетичним словом сприяють вихованню не лише кваліфрікованих фрахівців, але й духовно багатих особистостей.

Ключові слова: гуманізачія, зміст освіти, знання, цінності, інтеграція, професійна підготовка,, технічний профріль, засоби інтеграції, художня література.

The article substantiates the expediency of using an integrative approach to the humanization of professional training for technicians. Such problems as non-integration of knowledge, irrelevancy of the obtained knowledge to vital and professional needs, as well as constant growing of material values over spiritual ones are revealed. The solution to these problems lies in the development of humanistic paradigms, in particular the humanization of the content of education in the training for technicials in institutions of higher and vocational education. It has been emphasized that based on the priority tasks of modern pedagogy, which aim is to identify humanistic aspects in vocational education, it is advisable to use the means of integrating students' knowledge, skills and values to form a creative personality and a highly qualified professional possessing valuable knowledge and skills, common views and system of universal and professional values. It has been shown that each discipline or innovation project has its own place in the content of education, which turns into a giant accumulation of facts, where information is constantly updated, but practically not folded or archived. The negative consequences of incorrect use of such general scientific category as "integration", which leads to discrediting the idea of integrative learning, are highlighted, However, there are a number of scientific papers where the integration of professional and universal components of knowledge and values in the formation of creative personality as one of the most important and difficult issues is researched. It is substantiated that natural sience disciplines have significant reserves for the humanization of the content of education, since scientific thought is mainly based on the integral criteria of truth. It is emphasized that one of the uncommon, although effective, means of improving professional training is the integration of technical knowledge and fiction, and a number of specific examples are given. It is concluded that technical knowledge in harmony with a beautiful poetic word contributes to the education of not only qualified professionals but also spiritually rich individuals.

Key words: humanization, content of education, knowledge, values, integration, professional training, technical profile, means of integration, fiction.
Постановка проблеми у загальному вигляді. Однією 3 давніх проблем освіти $€$ «неінтегрованість знання, розрив між знанням та індивідуальністю, за якого вивчені фракти та теорії, придбані навички маніпулювання даними (внутріпредметна техніка) не пропущені через особистість і, як наслідок, у довгостроковому плані не пов'язуються осо- бистістю ні з існуючим світом, ні з її внутрішніми або зовнішніми, наприклад, профресійними потребами. Причина такого стану полягає в особливій соціальній ізольованості та відчуженості школи від істотної частини проблем, що стосуються практичного життя людини нині у цьому суспільстві» [5, c. 49]. 
Нині в системі освіти спостерігаємо жорстоку боротьбу за виживання, яка дедалі більше охоплює школу. На думку академіка С. Гончаренка, гуманістичні орієнтири людей замінюють матеріальні цінності: речі, вишукані дачі, парки авто, яхти, задоволення і влада. Запорука успішності формування духовно зрілого, креативного індивіда - гуманізація освіти, її «олюднення», достатня увага до індивіда кожного учня, створення найсприятливіших умов для його становлення й самореалізації. Заміна технократичного виклику людству - завдання гуманістичних парадигми або орієнтації [2, с. 19]. Завдяки гуманізації освіти забезпечуються свобода думки й вибір поведінки, розвивається світогляд, поєднуються складові частини освіти й культури індивіда.

Аналіз останніх досліджень і публікацій. Проблему інтеграції деяких явищ і процесів у педагогіці поглиблено вивчають. Тут чільне місце посідає інтеграція технічних і гуманітарних знань, наукові поняття й художні образи, світоглядні складники, вузькофрахові й духовні, загальнолюдські цінності. Окреслену проблему досліджували у своїх наукових працях у таких аспектах: гуманізація освіти як запорука виховання творчої та духовно багатої особистості (С. Гончаренко [2]), гуманізм як освітня домінанта педагогічної дії (А. Самодрин [8], духовність у національній системі освіти (Д. Чернілевський [10]), фрормування духовно-моральних цінностей молоді (Є. Сурело [9]) та культурологічної компетентності (О. Федорцова [11]), інтеграція гуманітарних дисциплін (І. Савка [7], А. Карпов [4]), література як інструмент формування екзистенціального гуманізму (Л. Грисенко [4]), образ світу в контексті інтеграції змісту освітніх галузей мови й літератури та природознавства (М. Антонюк [1]) та ін.

Виділення не вирішених раніше частин загальної проблеми. Утім, чимало ії аспектів досліджені недостатньо. Першочергове завдання новітньої педагогіки, окрім іншого, - виявити гуманістичні аспекти фахової педагогіки засобами інтеграції знань, навичок і цінностей учнів, аби сорормувати творчу особистість професіонала зі справжніми фраховими знаннями й умілостями, єдиними світоглядом і системою загальнолюдських і фрахових цінностей.

Мета статті - обґрунтувати доцільність використання інтегративного підходу до гуманізації фрахової підготовки у професійній школі на основі використання художніх творів у процесі вивчення технічних дисциплін.

Виклад основного матеріалу. Реалії життя кожної держави в будь-який історичний момент - це жнива освіти в її найширшому розумінні: навчання, виховання і розвитку у спеціально створених установах, освіти в сім'ї, освіти в побуті, освіти на історичних прикладах, освіти релігійної тощо. Саме показники цієї всезагальної освіти фрормують наш час, наш світ, розуміння свого місця в ньому. Сучасний світ незалежно від свого саморозуміння базується на традиціях та інноваціях. I ті, і ті можуть бути добрими чи злими, прогресивними чи регресивними, правдивими чи неправдивими. Безсумнівно, існують традиції добра, і так само існують обряди як тягар минулого.

Аналогічно 3 освітою: часто губляться добрі традиції, а сучасна освіта погрузла під тягарем обрядів. Сучасне суспільство рветься дати освіту, та ще й вищу, якнайбільшому числу молоді та не ураховує суворої прози сучасного життя. $Є$ діти, яким просто пощастило з батьками: ці діти будуть щасливими й освіченими, добрими фрахівцями чи вченими за умов будь-якої, навіть найнужденнішої держави. Є діти, яким пощастило із країною - вони досягнуть вершин за рахунок розумної системи державної та приватної освіти. $€$ діти, яким пощастило з талантом і характером - вони виб'ються в люди за будь-яких умов. Але є ще мільйони дітей, котрі позбавлені цього, а право на життя, на освіту, на щастя, на духовний розвиток однакове для всіх.

Освіта - це і засоби масової інформації, але, «на превеликий жаль, ЗМІ (телебачення) перекреслюють благі наміри системи освіти <...> активність подається як нахабство, рвацтво; спілкування - як розкованість, спритність - як авантюризм і т. д. За неформальних обставин відбувається освітній процес - зміна внутрішнього образу людей різного віку. Здавалося б, саме телебачення повинно взяти на себе фрункцію демократизації, гуманізації суспільної свідомості та соціального життя, виховання толерантності, самостійності, навчання суб'єктивній позиції. Внаслідок чого - повернути в свідомість людей категорію совісті <..> Але, на жаль, це не так!» [10, с. 98].

Із наймолодшого дитинства нині дитина бачить на екрані карикатурні фрізіономії, насильство, бруд, стрілянину, смерть, побоїща і звикає до цього. Звичайно, ЗМІ повинно адекватно відображати реалії, але йдеться про акценти. Навіть невелика цівочка добра і теплоти з екрану знаходить відгук у дитячому серці. Недаремно писав Тарас Шевченко: «Раз добром зогріте серце - вік не захолоне». Освіту коригують побут і політика, друзі та сусіди, приклади хабарництва і продажності частини педагогів, аморальна поведінка батьків.

Власне, тут чітко проявляються не добро й розуміння різних освітніх аспектів, а їхня боротьба, котра не обирає засобів. Усі навчальні дисципліни, інноваційні чи прожектерські пропозиції виборюють власне місце в сутності освіти, застосовуючи різної переконливості аргументи та методи втілення.

Така сутність стає гігантським накопиченням фрактів, позаяк «вчені довели, що доросла людина зберігає у своїй пам'яті не більше 5\% того, що 
вона вивчала у школі. То, можливо, варто спробувати визначити ці п'ять, нехай навіть 25\% вартого вивчення матеріалу, і не зубрити Монблани розрізнених непотрібних фрактів. Погано, коли випускник школи не знає нічого, але ще гірше, якщо він запам'ятав якусь єрунду» [3, с. 82]. Інакше кажучи, істотні проблеми з'являються вже на етапі формування змісту знань, що й казати про ціннісні, духовні плани освіти.

Пошуки нових методів, настирливе прагнення знайти лік від усіх невдач, гонитва за універсальними ресрормами та сподівання на кардинальні зміни. Можливо, належить розпочати з очевидного, не втрачаючи наполегливості й терпіння. Таке голослівне очевидне $є$ ідеєю всезагальних взаємозв'язку, єдності, гармонії людського життя, шляхом до високої цілісності матеріального в людській душі, цілісності, завдяки якій людина вважається Людиною.

У сучасній педагогічній науці загальнонаукова категорія «інтеграція» використовується, м'яко кажучи, не завжди коректно. Поруч із ґрунтовними науковими дослідженнями сутності та можливостей інтеграції в освіті категорію «інтеграція» вживають у ряді досліджень, особливо дисертаційних із педагогіки, до речі і не до речі, не розуміючи її сутності та функцій, а це призводить до девальвації та вульгаризації цього поняття, як наслідок - до дескридитації самої ідеї інтегративного навчання. Водночас інтеграція професійного та загальнолюдського компонентів знань-цінностей у фрормуванні творчої особистості фрахівця $є$ одним із найважливіших і найскладніших завдань сучасної освіти. Досить часто можна натрапити на «начинених» Ґрунтовними та систематизованими знаннями фрахівців, нездатних такі знання творчо застосовувати на якісно новому рівні. Звісно, для науки притаманний власний випробуваний арсенал формування творчого хисту (йдеться про природою наділених людей). Мислення людини відображає суть об'єктивного світу в усіх його взаємозв'язках і взаємозумовленості, що необхідно врахувати у побудові навчального процесу у профресійній школі.

Зазвичай вважають, що фрормувати образне, художнє мислення та розвивати художній смак учнів повинні суто гуманітарні дисципліни, однак значними резервами гуманітаризації навчання володіють і предмети природничого циклу, позаяк упродовж тривалого розвитку, зокрема в часи Ренесансу, наукова думка ґрунтувалася на інтегральних критеріях істини. Наука не лише копіювала реальність, а й відтворювала креативне ставлення до неї, створюючи особливі образи такої реальності логічним мисленням, апелюючи до людської свідомості.

Водночас непросто переоцінити значення уяви, вимислу, емоцій для відтворення світу в художніх образах, звернених передусім до людської підсвідомості. Тільки тісний взаємозв'язок свідомого з підсвідомим, логічного 3 інтуїтивно-емоційним мисленням - запорука забезпечення єдиного та творчого сприйняття довкілля. Спроби поєднати науку та мистецтво не механічно, а на основі реально існуючих глибинних зв'язків завжди приводили до появи нестандартних думок, створення визначних мистецьких творів, відкриттів у науці. Наприклад, вчений і митець Л.-Б. Альберті ще у $\mathrm{XV}$ ст. намагався поєднати наукові та мистецькі стилі, застосувавши математичні методи до архітектури й образотворчого мистецтва, розвиваючи вчення про перспективу.

Часом науку порівнюють зі сходами, де кожна наступна сходинка будується на основі попередньої. Мистецтво в цьому алегоричному контексті схоже на «помах крил», на прекрасний гірський хребет, де кожна вершина зберігає індивідуальність і може існувати відносно самостійно. Аналіз відмінностей у когнітивних засобах науки та мистецтва дає можливість перейти до наступного етапу - їх інтеграції.

Доцільним $\epsilon$ використання інтегративних зв'язків технічних знань і художньої літератури. Загалом вважають, що такі зв'язки мають застосовуватися переважно у закладах загальної середньої освіти, однак і у закладах вищої освіти, а тим більше - професійно-технічної такі зв'язки $€$ дуже ефективними та позитивно впливають як на гуманітарну, так і на технічну підготовку студентів чи учнів.

Наведемо декілька конкретних прикладів.

Випаровування рідин. «Дід Яків покликав до себе Сергійка та Олега. - Немає в мене сина, сказав він, - що передати йому ремесло своє... Вам, хлоп'ята, скажу, чому в моїх глечиках вода холодніє... Кульбабу знаєте? Летючки 3 неї треба у глину замісити... В горні вони згорять і тонесенькі дірочки залишаться, тонші за волосинку. Через них вода потрошку просочується, а, отже, випаровується. Від цього вона і холоніє в глечику» (Володимир Кисельов, «Любов і картопля»). Наведений уривок можна використати для пояснення причини охолодження рідини при ії випаровуванні та наголосити, що шляхом багаторічних і багаторазових спостережень народні умільці навчилися робити правильні фрізичні висновки, як цей дідусь із Чернігівщини.

Властивості матеріалів. У цьому фантастичному оповіданні показано створення надмірного універсального матеріалу (акваліду) з одної-однісінької сировини - води. При вивченні нових конструкційних матеріалів із заданими властивостями можна запропонувати учням і студентам описати випробування властивостей акваліду, який дає поняття про сучасні вимоги до фрізико-хімічних властивостей матеріалів: «На брусок опускалися 
сталеві молоти, його хапали кліщі 3 надтвердих сплавів, то розжарювали брусок, то кидали його в рідкі гази, охолоджені майже до абсолютного нуля, занурювали його в луги і кислоти, заштовхували у вибухову камеру, піддавали згубним випромінюванням. Нарешті на підлогу впав брусок. Аквалід був точно такий, як до випробування. На ньому не було жодної подряпини» (Вадим Шефнер, «Дівчина біля урвища, або нотатки Ковригіна»).

Теплове випромінювання. При вивченні інорачервоних хвиль пропонуємо прослухати описання теплового променя та визначити вірогідність такого трактування фрізичного явища: «Від невидимого полум'я загорялися сосни, спалахував сухий дрік... Багато хто вважає, що вони концентрують інтенсивну теплоту в абсолютно непровідній для тепла камері... і кидають паралельними променями на той предмет, котрий обрали ціллю. Безсумнівно одне: тут діють теплові промені. Теплові невидимі промені замість видимого світла. Все, що тільки може горіти, перетворюється на язики полум'я від їх дотику» (Герберт Веллс, «Війна світів»).

Акустика. Вивчивши особливості людського голосу, молодий учений складає «алфравіт» для окремої людини і, користуючись ним, створює запис довільного тексту, який звучить голосом цієї людини (оповідання франтастичне). При вивченні голосності, висоти та тембру звуку можна обговорити, наскільки можлива така ситуація (Олександ Дашкієв, «Украдений голос»).

Незаслужено забуте у контексті гуманізації технічних знань українське поетичне слово. Постійне зведення тематики української літератури до провінціалізму або ж революційного пафосу призвело до того, що пошуки поетичних творів для уроків фрізики серед українських авторів практично відсутні.

Наприклад, багатогранний і різноплановий талант Ліни Костенко торкнувся проблеми, яку не можна не зачепити на уроках фрізики - нерозумного використання атомної енергії. У циклі «Інкрустації» читаємо: «Атомний Вій опустив бетонні повіки, / Коло окреслив навколо себе страшне. / Чому Звізда-Полин упала в наші ріки?! / Хто сіяв цю біду і хто її пожне? / Загидили ліси і землю занедбали / Поставили АЕС в верхів'ї трьох річок. / То хто ж ви є, злочинці, канібали?! / Ударив чорний дзвін. І досить балачок». А далі: «Роса як смертний піт на травах, на горіхах. / Але найбільше стронцію у стріхах. / Хто це сказав, що стріхи - традиційні? / У нас і стріхи вже радіаційні». Не менш тривожними є рядки 3 «Летючих катренів»: «Ми - атомні заложники прогресу / Вже в нас нема ні лісу, ні небес. / Так і живем від стресу і до стресу / Абетку смерті маємо - AEC». Такими словами звертається поетеса до тих, хто злочинно використав атомну енергію, яка б мала бути благодійницею людства.
Яскравою ілюстрацією взаємозв'зку науки та мистецтва можуть служити поетичні рядки Ліни Костенко: «Коли у тузі вічної розлуки / Супутник людям голос подає, / Я думаю: у точності науки, / Яке мистецтво і натхнення $€ . . . »$.

Таких прикладів можна навести багато, адже точні технічні знання в гармонії з талановитим поетичним словом сприятимуть вихованню не лише хороших фрахівців, але й духовно багатих особистостей. Таким чином, інтегральне поєднання науки та мистецтва, наукового поняття і художнього образу наближає нас до Вічного ідеалу цілісної особистості: розумної та духовної, внутрішньо величної та доброї, раціональної та щедрої.

Висновки. Тісно взаємодіючи, історію творять люди та природа, тож основне історичне поняття розвиток - охоплює низку розмаїтих елементів, чинників, проявів. Таке поняття природно поєднує розвиток суспільства загалом, науки, техніки, культури й мислення. Відтворити таку цілісність у процесі навчання, показати молоді світ у вигляді складної системи розмаїтих взаємозв'язків поміж начебто найвіддаленішими об'єктами та процесами було й зостається одним із найактуальніших завдань школи. Завдяки такому підходу учні та студенти можуть повноцінно перейти у просресійне буття як вервечку взаємодій зі складним розмаїттям знань, де суто предметні знання - важливі, та аж ніяк не достатні для належного орієнтування й можливості посісти власне місце в житті. Звичайно, в кожному конкретному випадку викладач добирає найдоцільніші, на його думку, уривки, враховуючи особливості та мету заняття, склад навчальної групи, обсяг і складність матеріалу, часові можливості тощо. Наш досвід переконує, що, займаючи небагато навчального часу, такі літературні мікроепізоди пожвавлюють заняття, допомагають освоїти предмет, а також служать цікавим матеріалом для позанавчальної діяльності роботи.

Подальші перспективи у цьому напрямі вбачаємо у дослідженні конкретних методик інтеграції для окремих технічних спеціальностей.

\section{БІБЛІОГРАФІЧНИЙ СПИСОК:}

1. Антонюк М.А. Поняття наукової картини світу та образу світу в контексті інтеграції змісту освітніх галузей «мови й літератури (літературний компонент)», «математика», «природознавство». Технології інтеграції змісту освіти : зб. наук. праць Всеукр. круглого столу, м. Полтава, 12 берез. 2018 р. Полтава : ПОІППО, 2018. Вип. 10. С. 127-141.

2. Гончаренко С. Гуманізація освіти - запорука виховання творчої та духовно багатої особистості. Дидактика професійної школи. 2005. Вип. 3. C. $19-23$.

3. Гончаренко С. Зміст загальної освіти і її гуманітаризація. Неперервна профресійна освіта: проблеми, пошуки, перспективи. Київ : Віпол. 2000. C. 81-107. 
4. Грисенко Л.П. Сучасна література як інструмент формування екзистенціального гуманізм. Гуманізація - найкоротший шлях до особистості : матеріали Всеукр. наук.-практ. майстерні м. Кременчук, 13 вересня 2019 р. Кременчук : Методичний кабінет, 2019. C. 215-220.

5. Карпов А.О. Научное познание и системогенез современной школы. Вопросы фрилософрии. 2003. № 6. C. 37-53.

6. Козловська І.М. Гуманістичні аспекти професійної педагогіки в контексті інтегративного підходу до освіти. Нові технології навчання. 2008. Вип. 55. Ч. 1. C. $37-43$.

7. Савка І.В. Впровадження вибіркових інтегрованих курсів під час підготовки майбутніх фрахівців гуманітарного профілю. Науковий вісник Ужгородського університету. 2017. Вип. 1. С. 249-251.

8. Самодрин А.П. Гуманізм як освітня домінанта педагогічної дії. Гуманізація - найкоротший шлях до особистості : матеріали Всеукр. наук.-практ. Май- стерні, м. Кременчук, 13 вересня 2019 р. Кременчук : Методичний кабінет, 2019. С. 9-13.

9. Сурело Є.А. Формування духовно-моральних цінностей в учнів молодшого шкільного віку. історико-педагогічний огляд. Формування цінніснозмістовної сорери дітей дошкільного та молодшого шкільного віку : матеріали обл. наук.-практ. конфр., м. Дніпро, 28 берез., 2018 р. Дніпро, 2018. C. $500-505$.

10. Чернілевський Д.В. Проблеми національної системи освіти і її входження в Болонський процес. Сучасні інфоормаційні технології та інноваційні методики навчання у підготовці фрахівців: методологія, теорія, досвід, проблеми. 2006. Вип. 9. C. 97-102.

11. Федорцова О.Г. Формування культурологічної компетентності майбутніх інженерів енергетиків у процесі вивчення гуманітарних дисциплін : дис. ... канд. пед. наук : 13.00 .04 / Житомирський держ. ун-т ім. Івана Франка. Житомир, 2016. 311 с. 